\title{
SIGNIFICANCE EVALUATION OF ENVIRONMENTAL ASPECTS
}

The identification of environmental aspects is an essential premise for implementation of EMS in a production company, but not a sufficient one. In order to effectively reduce negative environmental impacts, first it is necessary to undertake a thorough examination of given environmental aspects. For this purpose, several methods can be used. In this article, 3 such methods are described in detail, namely the method of Total pair comparison, the Rank method and the Saaty method. A properly prepared classification of all involved environmental aspects, evaluated by their importance can be considered a first step for successful environmental pollution reduction or elimination. In order to determine and quantify which environmental aspects have the highest priority, the Pareto analysis and Lorenz curve method can be used.

\begin{abstract}
1. Introduction
To establish a functional and successful environmental system in a company, the first key step is to identify all aspects with potentially negative impact on the environment, including a significance analysis, with the goal to determine which aspects are the most harmful for the environment. The most harmful aspects are then called significant environmental aspects. These aspects can be controlled directly, modifying the main production process, or indirectly through supporting processes, such as the distribution, packaging, transport, design, etc. The approach the company takes to manage their environmental system, depends on company's economic situation, market share and competition ability. Those companies that inflict significant impacts on environment are required to create a system for better identification, monitoring and evaluation of significant environmental aspects.
\end{abstract}

\section{Environmental aspects identification and monitoring}

It is important to mention that environmental aspects identification does not require meticulous investigation of product life cycle, only the production processes. Aspects that were identified as important, must be monitored, managed and analyzed, to prevent, or at least minimize the scope of potential environmental damage. For this reason it is important to systematically and continually measure and monitor significant environment damaging aspects during EMS implementation. To identify environmental aspects, it is important to focus on:

- Specific significance of each environmental aspect, considering the state legislation and environmental norms requirements,

- The frequency of performed activities, or provided services, frequency of goods and services purchase related to identified environmental aspects,
- The probability of environmental aspect occurrences,

- Significance and potential impact of given environmental aspect.

In the example below, a given company identified 7 groups of environmental aspects (Table 1). To determine their influence on environment, following three methods were applied, namely:

- The method of total pair comparison,

- The rank number method,

- Analytic Hierarchy Process - AHP method also called Saaty method[3].

The above mentioned methods indicate the sequence rank number of the most significant aspects, which deserve more attention. Electro energy consumption causes depletion of available natural resources and at the same time represents high production costs. Excessive electro energy consumption is caused mainly by high performance engines of wood processing facilities. As the wood processing industry relies heavily on high performance machines with considerable electro energy consumption, the old obsolete wood processing facilities should be gradually replaced by new energy efficient models.

Alternatively, the company might consider investing into electro energy generators based on ecological systems and clean ecological technologies. Water energy can be used to produce electricity in small water energy power plants. Water energy belongs among renewable energy sources. For renewable energy projects the most considerable cost item is the initial investment. After the company paid for the renewable energy technology, the most significant factor affecting the product price are operational costs. These however are relatively low for renewable energy technologies.

Overall evaluation $H_{i}$ of each aspect can be calculated by multiplication of all values for given row, expressed as $H_{i}=\prod a_{i j}$.

\footnotetext{
* Marcela Malindzakova

Process Control and Geotechnology, Institute of Control and Informatization of Production Processes, Faculty of Mining, Ecology, TU Kosice,

Slovakia, E-mail: marcela.malindzakova@tuke.sk
} 


\begin{tabular}{|c|c|c|c|c|c|c|c|c|c|c|c|}
\hline \multicolumn{12}{|c|}{ Aspect groups } \\
\hline 1 & \multicolumn{2}{|c|}{2} & \multicolumn{2}{|l|}{3} & \multicolumn{2}{|l|}{4} & \multicolumn{2}{|c|}{5} & \multicolumn{2}{|c|}{6} & 7 \\
\hline Sawdust & $\begin{array}{c}\text { Electro } \\
\text { energy } \\
\text { consump- } \\
\text { tion }\end{array}$ & $\begin{array}{c}\text { Electro } \\
\text { energy } \\
\text { consump } \\
\text {-tion }\end{array}$ & Wood & Wood & Bark & Bark & $\begin{array}{l}\text { Cutting } \\
\text { discs } \\
\text { attrition }\end{array}$ & $\begin{array}{l}\text { Cutting } \\
\text { discs } \\
\text { attrition }\end{array}$ & $\begin{array}{l}\text { Tools } \\
\text { attrition }\end{array}$ & $\begin{array}{c}\text { Tools } \\
\text { attrition }\end{array}$ & $\begin{array}{l}\text { Chemicals } \\
\text { consump- } \\
\text { tion }\end{array}$ \\
\hline Sawdust & Wood & $\begin{array}{c}\text { Electro } \\
\text { energy } \\
\text { consump } \\
\text {-tion }\end{array}$ & Bark & Wood & Bark & Bark & $\begin{array}{l}\text { Tools } \\
\text { attrition }\end{array}$ & $\begin{array}{l}\text { Cutting } \\
\text { discs } \\
\text { attrition }\end{array}$ & $\begin{array}{l}\text { Chemicals } \\
\text { consump- } \\
\text { tion }\end{array}$ & & \\
\hline Sawdust & Bark & $\begin{array}{c}\text { Electro } \\
\text { energy } \\
\text { consump } \\
\text {-tion }\end{array}$ & $\begin{array}{l}\text { Cutting } \\
\text { discs } \\
\text { attrition }\end{array}$ & Wood & Bark & Bark & $\begin{array}{c}\text { Chemicals } \\
\text { consump- } \\
\text { tion }\end{array}$ & & & & \\
\hline Sawdust & $\begin{array}{l}\text { Cutting } \\
\text { discs } \\
\text { attrition }\end{array}$ & $\begin{array}{c}\text { Electro } \\
\text { energy } \\
\text { consump } \\
\text {-tion }\end{array}$ & $\begin{array}{l}\text { Tools } \\
\text { attrition }\end{array}$ & Wood & $\begin{array}{l}\text { Chemicals } \\
\text { consump- } \\
\text { tion }\end{array}$ & & & & & & \\
\hline Sawdust & $\begin{array}{c}\text { Tools } \\
\text { attrition }\end{array}$ & $\begin{array}{c}\text { Electro } \\
\text { energy } \\
\text { consump } \\
\text {-tion }\end{array}$ & $\begin{array}{l}\text { Chemicals } \\
\text { consump- } \\
\text { tion }\end{array}$ & & & & & & & & \\
\hline Sawdust & $\begin{array}{l}\text { Chemicals } \\
\text { consump- } \\
\text { tion }\end{array}$ & & & & & & & & & & \\
\hline
\end{tabular}

Environmental aspect identification

Table 2

\begin{tabular}{|c|c|c|c|c|}
\hline Aspect group & Impact & Evaluation & Significance [\%] & Weight $w_{i}$ \\
\hline Sawdust & Waste production & 1 & $5 \%$ & 0.05 \\
\hline Electro energy consumption & Natural resources consumption & 4 & $19 \%$ & 0.19 \\
\hline Wood & Natural resources consumption & 3 & $14 \%$ & 0.14 \\
\hline Bark & Pollution production & 0 & $0 \%$ & 0.00 \\
\hline Cutting discs attrition & Pollution production & 6 & $28 \%$ & 0.28 \\
\hline Tools attrition & Pollution production & 5 & $24 \%$ & 0.24 \\
\hline Chemicals consumption & Dangerous waste production & 2 & $10 \%$ & 0.10 \\
\hline Total & & 21 & $100 \%$ & 1.00 \\
\hline
\end{tabular}

Saaty matrix

Table 3

\begin{tabular}{|c|c|c|c|c|c|c|c|c|c|c|}
\hline & Sawdust & $\begin{array}{c}\text { Electro } \\
\text { energy con- } \\
\text { sumption }\end{array}$ & Wood & Bark & $\begin{array}{l}\text { Cutting } \\
\text { discs } \\
\text { attrition }\end{array}$ & $\begin{array}{c}\text { Tools } \\
\text { attrition }\end{array}$ & $\begin{array}{c}\text { Chemicals } \\
\text { consumptio } \\
n\end{array}$ & $H_{i}$ & $R_{i}$ & $\begin{array}{c}\text { Weights } \\
w_{i}\end{array}$ \\
\hline Sawdust & 1 & $1 / 7$ & $1 / 6$ & $1 / 2$ & $1 / 5$ & $1 / 9$ & $1 / 3$ & 0.000 & 0.263 & 0.030 \\
\hline $\begin{array}{l}\text { Electro energy } \\
\text { consumption }\end{array}$ & 7 & 1 & 2 & $1 / 3$ & 4 & 5 & 5 & 466.667 & 2.406 & 0.272 \\
\hline Wood & 6 & $1 / 2$ & 1 & $1 / 4$ & 3 & $1 / 2$ & $1 / 3$ & 0.375 & 0.869 & 0.098 \\
\hline Bark & 2 & 3 & 4 & 1 & $1 / 6$ & $1 / 5$ & $1 / 3$ & 0.267 & 0.828 & 0.094 \\
\hline Cutting discs attrition & 5 & $1 / 4$ & $1 / 3$ & 6 & 1 & $1 / 7$ & 3 & 1.071 & 1.010 & 0.114 \\
\hline Tools attrition & 9 & $1 / 5$ & 2 & 5 & 7 & 1 & 7 & 882.000 & 2.635 & 0.298 \\
\hline $\begin{array}{l}\text { Chemicals } \\
\text { consumption }\end{array}$ & 3 & $1 / 5$ & 3 & 3 & $1 / 3$ & $1 / 7$ & 1 & 0.257 & 0.824 & 0.093 \\
\hline & & & & & & & & & 8.835 & 1.000 \\
\hline
\end{tabular}


From that we get $R_{i}=H_{i}^{1 / n}$ (or $\left.\left(\prod_{i} a_{i j}\right)^{\frac{1}{n}}\right)$. Sum on all $R_{i}$, expressed as $\sum_{i} R_{i}=R$ serves for weight calculation $w_{i}=\frac{R_{i}}{R}$.

The weights are then used to determine the rank for each environmental aspect.

The rank numbers and weights calculated using different methods are shown in Table 4. The final rank numbers of all monitored environmental aspects are based on their weight values. After displaying the rank numbers using polygons chart (Fig. 1), different position numbers of individual environmental aspects indicate their significance. In this specific example, the most significant difference can be observed for chemicals consumption, which indicates that further inquiry for this environmental aspect is needed. In cases like this the Spearman's rank correlation coefficient can be used.

$$
R=1-\frac{6 \cdot \sum d_{i}^{2}}{n \cdot\left(n^{2}-1\right)},
$$

where:

$d_{i} \quad$ - is the difference in environmental aspect rank number for each used methods,

$n=7$ is the number of identified and evaluated environmental aspects.

The results of the correlation methods are shown in Table 5. It is apparent that between the method of total pair comparison and the Saaty method there is a strong correlation $R=0.79$. Between the method of total pair comparison and the rank method, the relation is insignificant. It is also advisable to calculate "average" of all three methods as indicated by correlation coefficients for each method and the "average" $(R=0.82 ; 0.75 ; 0.89)$.

After retrieving "representative" rank numbers based on significance of individual environmental aspect, it is apparent that the first 3 environmental aspects in the overall evaluation show a $63 \%$ influence. As shown in Pareto analysis and Lorenz curve results (Fig. 2), these 3 environmental aspects are the ones where the attention should be focused first. [1]
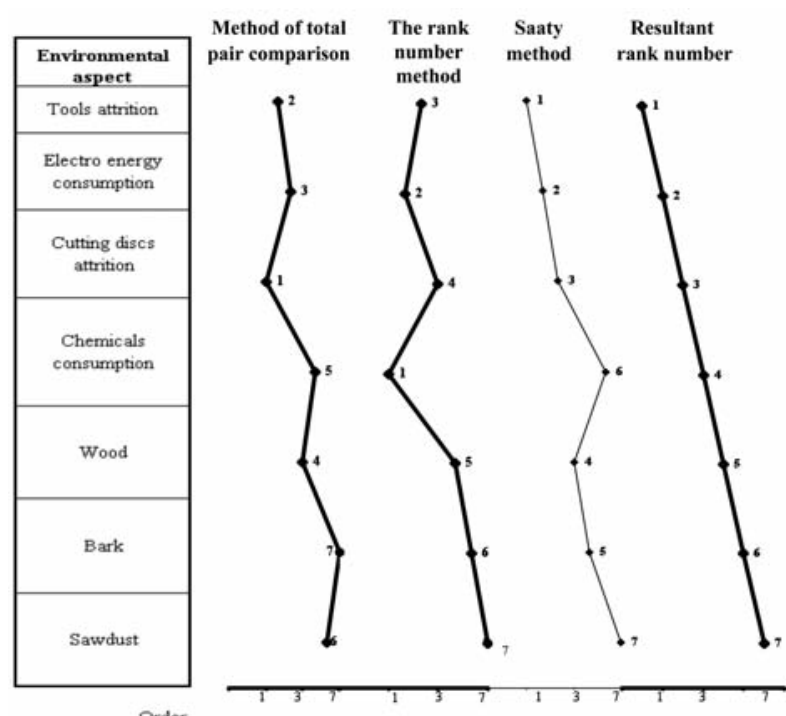

Fig. 1 Polygons of environmental aspect rank number for all applied methods

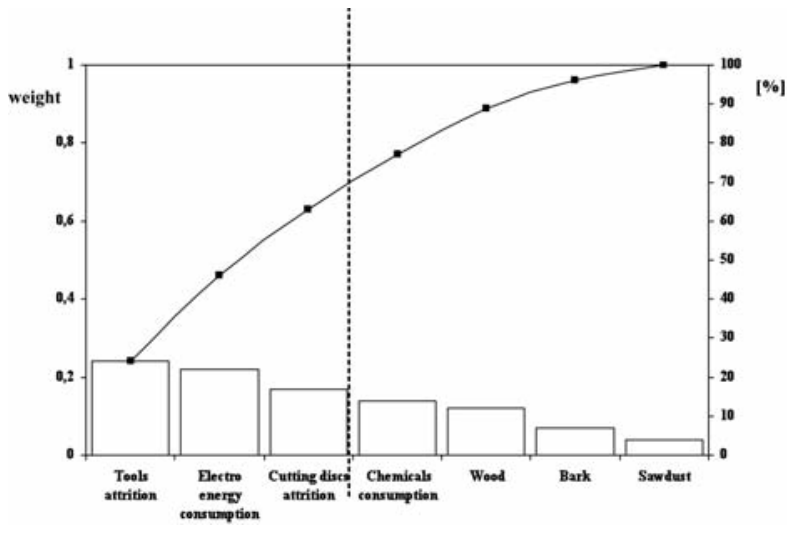

Fig. 2 Pareto analysis and Lorenz curve of environmental aspect evaluation

Evaluation of environmental aspects significance

Table 4

\begin{tabular}{|c|c|c|c|c|c|c|c|c|c|}
\hline \multicolumn{6}{|c|}{ Method } & \multirow{3}{*}{ Environmental aspect } & & & \multirow{3}{*}{$\begin{array}{c}\text { Final } \\
\text { sequence }\end{array}$} \\
\hline \multicolumn{2}{|c|}{ Of total pair comparison } & \multicolumn{2}{|c|}{ The rank number } & \multicolumn{2}{|c|}{ Saaty } & & & & \\
\hline R.n. & weight & R.n. & weight & R.n. & weight & & R.n. & weight & \\
\hline 1 & 0.28 & 4 & 0.12 & 3 & 0.19 & Cutting discs attrition & 2.7 & 0.20 & 3 \\
\hline 2 & 0.24 & 3 & 0.19 & 1 & 0.30 & Tools attrition & 2.0 & 0.24 & 1 \\
\hline 3 & 0.19 & 2 & 0.19 & 2 & 0.27 & Electro energy consumption & 2.3 & 0.22 & 2 \\
\hline 4 & 0.14 & 5 & 0.11 & 4 & 0.10 & Wood & 4.3 & 0.12 & 5 \\
\hline 5 & 0.10 & 1 & 0.23 & 6 & 0.09 & Chemicals consumption & 4.0 & 0.14 & 4 \\
\hline 6 & 0.05 & 7 & 0.05 & 7 & 0.03 & Sawdust & 6.7 & 0.04 & 7 \\
\hline 7 & 0.00 & 6 & 0.11 & 5 & 0.09 & Bark & 6.0 & 0.07 & 6 \\
\hline & 1.00 & & 1.00 & & 1.00 & & & 1.00 & \\
\hline
\end{tabular}




\begin{tabular}{|l|c|c|c|c|c|c|}
\hline \multicolumn{5}{|l|}{} & \multicolumn{5}{l|}{${ }_{i}^{2}-$} \\
\hline Environmental aspect & TPC /RN & TPC/SAAT & RN/SAAT & TPC/AVE & RN/AVE & SAAT/AVE \\
\hline Cutting discs attrition & 9 & 4 & 1 & 4 & 1 & 0 \\
\hline Tools attrition & 1 & 1 & 4 & 1 & 4 & 0 \\
\hline Electro energy consumption & 1 & 1 & 0 & 1 & 0 & 0 \\
\hline Wood & 1 & 0 & 1 & 1 & 0 & 1 \\
\hline Chemicals consumption & 16 & 1 & 25 & 1 & 9 & 4 \\
\hline Sawdust & 1 & 1 & 0 & 1 & 0 & 0 \\
\hline Bark & 1 & 4 & 1 & 1 & 0 & 1 \\
\hline$\sum d_{i}^{2}$ & 30 & 12 & 32 & 10 & 14 & 6 \\
\hline $\mathrm{R}$ & 0.46 & $\mathbf{0 . 7 9}$ & 0.43 & $\mathbf{0 . 8 2}$ & $\mathbf{0 . 7 5}$ & $\mathbf{0 . 8 9}$ \\
\hline
\end{tabular}

\section{Conclusion}

Regular and long-term monitoring of environmental aspects can help providing a proper company evaluation, in regard to adhering to state environmental legislation and fulfilling legislation limit for given country. Such monitoring also indicates the areas of environmental protection where the company must dedicate more effort and more financial investment.

A sudden change in one of the environmental aspects might indicate an incident in company operation. This information is vital for the management, for company's employees as well as for other organizations, especially considering social and civic responsibilities of the company. The implementation of new environmental and renewable sources technologies, can provide an increased yield of natural resources and might reduce the risk of negative impacts on environment. Therefore, such technologies are of increasing importance, especially to companies with positive attitude towards environmental and social issues. The recent increase in the number of projects focused on electrical energy production from renewable sources shows the importance and support of this research within the European Union.

\section{Acknowledgements}

This work was partially supported by grant VEGA 1/0571/10 from the Slovak Grant Agency for Science.

\section{Reference}

[1] BeNKOVA, M., FLOREKOVA, L., BOGDANOVSKA, G.: Systems of Quality Management (in Slovak), Elfa, s.r.o., Kosice, 2007, p. 220, ISBN 978-80-8086-066-0.

[2] STN EN ISO 14001 : 2005 Systems of Environmental Management (in Slovak). Poziadavky s pokynmi na pouzitie.

[3] MAJERNIK, M., HUSKOVA, V., BOSAK, M., CHOVANCOVA, J.: Appraisal Methodology of Impact to Environment (in Slovak), Strojnicka fakulta, TU Kosice, 2008, p. 212, ISBN 978-80-8073-947-8. 